\title{
MENGKAJ I POLITIK HUKUM KEBEBASAN BERAGAMA DAN BERKEYAKINAN DI INDONESIA
}

\author{
Muktiono \\ Fakultas Hukum Universitas Brawijaya Malang \\ E-mail: muktiono@hotmail.com
}

\begin{abstract}
Indonesia has entered the era of human rights characterized by increasingly massive domestication of the international human rights norms in national legal system. In such a situation, in fact, the rights to freedom of religion and of belief for minorities have not received their benefits and instead they become victims. This Article seeks to investigate how it can happen by using the legal politics analysis as perspective. Legal politics here will focus on how the governments of several regimes in Indonesia have used their legislation and policy to regulate matters relating to the rights to freedom of religion and belief. In addition, it will also see how the Constitutional Court contributed to this issue by influencing the legal politics as this Court is the sole authority in interpreting the constitutional right to the freedom of religion and belief thereby affecting its normation and implementation.
\end{abstract}

Key words: Religious minority group, human rights, legal politics of Indonesia

\begin{abstract}
Abstrak
Indonesia telah memasuki era hak asasi manusia yang ditandai dengan semakin masifnya domestifikasi norma-norma hak asasi manusia internasional dalam sistem hukum nasional. Dalam situasi tersebut ternyata hak atas kebebasan beragama dan berkeyakinan bagi kelompok minoritas belum mendapatkan kemanfaatannya dan justru mereka menjadi korban. Artikel ini berusaha untuk menyelidiki bagaimanakah hal tersebut bisa terjadi dengan menempatkan analisa politik hukum sebagai perspektifnya. Politik hukum disini akan berfokus kepada bagaimana pemerintah dari berbagai rezim telah menggunakan kebijakan legislasinya dalam mengatur masalah-masalah terkait hak atas kebebasan beragama dan berkeyakinan. Selain itu, juga akan dilihat bagaimana Mahkamah Konstitusi berkontribusi dalam mempengaruhi politik hukum tersebut karena lembaga tersebut merupakan pemegang otoritas satu-satunya dalam menafsir hak konstitusional atas kebebasan beragama dan berkeyakinan sehingga dengan sendirinya berpengaruh terhadap penormaan maupun implemetasinya.
\end{abstract}

Kata Kunci: Kelompok minoritas beragama dan berkeyakinan, hak asasi manusia, hukum, politik hukum Indonesia

\section{Pendahuluan}

Gelombang reformasi yang dimulai pada tahun 1998 telah membuka ruang baru bagi perdebatan terhadap "Prinsip Ketuhanan" mulai dari kelas-kelas di kampus, gedung parlemen, media massa, sampai dengan ke pengadilan konstitusi. Materi paling menonjol dalam perdebatan publik tersebut adalah tentang gugatan terhadap praktek-praktek diskriminatif yang telah diterima oleh kelompok beragama/ berkeyakinan minoritas akibat implementasi hukum dan kebijakan dari "prinsip ketuhanan". Advokasi oleh kelompok-kelompok penekan terhadap praktek negara yang diskriminatif tersebut menemukan momentumnya yang lebih kuat ketika Indonesia telah memasuki era Hak Asasi Manusia. Para aktivis tidak lagi mendapatkan labelisasi komunis/ atheis sehingga represi negara dan kelompok beragama berkurang sehingga semakin leluasa menempatkan konsep, prinsip, dan norma hak asasi manusia dalam perdebatan publik untuk mengkontestasi praktik "prinsip ketuhanan" meskipun dalam beberapa kasus masih terjadi intimidasi terhadap aktifitas ini teruma oleh kelompok radikal. Hak Asasi Manusia menjadi semakin popular dan 
menjadi alat pembelaan yang sangat efektif melawan tindakan-tindakan negara yang represif dan diskriminatif meskipun hasilnya masih jauh dari yang diharapkan.

Situasi untuk melakukan pemajuan hak kebebasan beragama dan berkeyakinan semakin kondusif, akan tetapi di sisi lain masih terdapat fakta bahwa pemenuhan hak atas kebebasan beragama dan berkeyakinan di Indonesia merupakan masalah rumit untuk diselesaikan. ${ }^{1}$ Antinomi eksis mulai dari level konstitusi sampai dengan penerapan norma pada tindakan administratif pemerintahan daerah yang mengakibatkan terjadinya serangkaian pelanggaran hak asasi manusia yang pada tingkatan paling serius telah mengakibatkan jatuhnya korban jiwa terutama bagi kelompok agama/ keyakinan minoritas. Prospek terhadap jaminan hak atas kebebasan beragama dan berkeyakinan di Indonesia saat ini menjadi permasalahan serius di tengah keterikatan Indonesia baik secara moral mau pun hukum terhadap norma-norma hak asasi manusia internasional.

Artikel ini berusaha untuk menyelidiki dan mengurai tentang fenomena inkonsistensi negara dalam pemenuhan hak kebebasan beragama dan berkeyakinan bagi kelompok minoritas yang terjadi di Indonesia sebagai bentuk paradoksal penegakan hak asasi manusia dalam pusaran tarik-menarik antara kepentingan kelompok mayoritas yang masih kuat memegang nilai-nilai partikularitas keagamaan mereka pada satu sisi dan tuntutan nilai-nilai hak asasi manusia yang bersifat universal dan telah menjadi hukum nasional di sisi lainnya. Dengan demikian diharapkan agar terungkap bagaimana peran para aktor yang terkait dalam proses diskriminasi berbasis agama dan kepercayaan di Indonesia terutama menyangkut sistem hukum dan penegakannya di Indonesia seperti Pengadilan, Pemerintah, dan lembaga keagamaan. Kasus yang sangat dominan menjadi bahan analisa dari penelitian ini adalah Putusan Mahkamah Konstitusi yang menguatkan eksistensi undang-undang penodaan agama yaitu Putusan

Agnes Dwi, "Solidaritas Bagi Kebebasan Beragama", J urnal Maarif, Vol 5 No. 2 Tahun 2010, J akarta: Maarif Institute, hlm, 115-122
Mahkamah Konstitusi No. 140/ PUU-VII/ 2009 tentang Penguj ian Undang-Undang Nomor 1/ PNPS/ Tahun 1965 Tentang Pencegahan Penyalahgunaan dan/atau Penodaan Agama. Kasus tersebut dipilih karena akan mempengaruhi praktik penegakan hak kebebasan beragama dan berkeyakinan di Indonesia mulai dari proses legislasi atau pembuatan hukum yang derajatnya di bawah konstitusi hingga pada praktek di tingkat administrasinya. Kekhawatiran terjadinya simplifikasi dalam menganalisa permasalahan pelaksanaan hak kebebasan beragama dan berkeyakinan di Indonesia mungkin saja terjadi apabila hanya berangkat pada kasus undangundang penodaan agama, tetapi Artikel ini memang tidak ditujukan untuk melihat permasalahan kebebasan beragama dan berkeyakinan dari seluruh sudut pandang karena keterbatasan ruang untuk mendiskusikan kompleksitas permasalahan. Sehingga uraian yang diberikan dalam artikel ini setidaknya diharapkan agar mampu berkontribusi dan menjadi bagian dari suatu analisa yang komprehensif dalam melihat kasus-kasus dan permasalahan kebebasan beragama dan berkeyakinan di Indonesia.

Bagian Kedua Artikel ini akan memberikan deskripsi singkat tentang paradok pengaturan hak atas kebebasan beragama dan berkeyakinan di Indonesia mulai dari era orde lama Soekarno hingga era Orde Baru Soeharto yang melakukan diskriminasi dalam kebijakan publik terkait hak beragama dan berkeyakinan terutama bagi kelompok minoritas. Setelah itu, pada bagian Ketiga akan dikaji tentang masifnya penormaan hak asasi manusia internasional dalam sistem hukum nasional Indonesia pada era reformasi pasca tumbangnya Presiden Soeharto yang justru menimbulkan antinomi baru karena pada tataran empiris justru kekerasan berbasis agama semakin marak dan mengalami perubahan pola pelanggaran yang semula hanya bersifat vertikal dalam relasi negara terhadap warganegara namun kemudian ditambah lagi dengan pola baru yaitu relasi kelompok agama mayoritas-minoritas dan dalam beberapa kasus melalui sponsor negara. Bagian Kempat akan secara khusus menyoroti bagaimana praktek penafsiran pengadilan konstitusi yang telah 
berpengaruh terhadap proses pembentukan hukum nasional dan dan daerah serta penerapannya yang semata-mata dibentuk untuk melegitimasi pelanggaran hak kebebasan beragama dan berkeyakinan terhadap kelompok minoritas yang telah dijamin di dalam konsitusi dan peraturan perundang-undangan lainnya di Indonesia maupun internasional. Sebagai bagian penutup maka artikel ini akan menyimpulkan tentang prospek atas konstruksi normatif dan implementasi dari hak atas kebebasan beragama dan berkeyakinan di Indonesia serta saran dan kritik apa yang bisa diberikan sehingga jaminan hak tersebut terutama bagi umat beragama/ berkeyakinan minoritas dapat di tegakkan secara adil dan berkelanjutan.

\section{Pembahasan}

Paradigma Sejarah Pengakuan Negara Terhadap Hak Atas Kebebasan Beragama dan Berkeyakinan di Indonesia

Preamble Undang-Undang Dasar Negara Republik Indontsia Tahun 1945 menegaskan tentang dasar negara yang diantaranya yaitu “...Negara Republik Indonesia, yang berkedaulatan rakyat dengan berdasar kepada Ketuhanan Yang Maha Esa...". Kemudian dalam batang tubuh UUD 1945 diperinci lagi tentang hak konstitusional atas kebebasan beragama dan berkeyakinan dalam bab khusus yang secara eksplisit berjudul "agama" dengan penjabaran pasalnya sebagai berikut: pertama, Negara berdasar atas Ketuhahan Yang Maha Esa; dan kedua, Negara menjamin kemerdekaan tiaptiap penduduk untuk memeluk agamanya masing-masing dan untuk beribadat menurut agamnya dan kepercayaannya itu.

Teks "Ketuhanan Yang Maha Esa" pada Preamble UUD 1945 sebenarnya merupakan versi revisi dari teks aslinya yaitu “...Ketuhanan, dengan kewajiban menjalankan syari'at Islam bagi pemeluknya,...". Tujuh kata yang menegaskan eksistensi hukum Islam kemudian dihapus dengan pertimbangan untuk membuat umat non-muslim merasa terayomi dalam konstitusi dan tidak terkesan diskriminatif. Penghapusan tujuh kata tersebut tidak kemudian mengakhiri keinginan kelompok Islam idealis untuk terus memperjuangkan kembalinya tujuh kata tersebut dalam ketatanegaraan di Indonesia. ${ }^{2}$ Perjuangan untuk formalisasi nilai-nilai Islam hingga saat ini masih terus berlangsung dengan kadar yang selalu berubah-ubah. Sebagai contoh adalah munculnya kembali partai-partai politik berasaskan Islam juga fenomena munculnya usaha untuk membuat peraturan daerah yang ingin menegakan hukum Islam. ${ }^{3}$

Hukum bekerja dalam sistem politik yang memberikan ruang bagi beberapa elemen negara dan masyarakat untuk saling berinteraksi satu dengan yang lain. Hukum dan kebijakan (legal politics) yang diambil oleh Pemerintah akan mempunyai kemampuan untuk menjelaskan bagaimanakah relasi antara suatu norma hukum yang abstrak dimaknai dan diimplementasikan pada tingkat yang paling konkrit. Oleh sebab itu, menelusuri jejak rekam hukum dan kebijakan terkait dengan hak atas kebebasan beragama dan berkeyakinan di masing-masing rezim pemerin-tahan di Indonesia akan membantu memberikan gambaran tentang bagaimanakah hukum bekerja dan sejauh mana juga telah mencapai tujuannya.

Pada masa orde lama (1950-1965), Presiden Soekarno mengeluarkan Penetapan Presiden No.1/PNPS Tahun 1965 yang memberikan tafsir terhadap keterkaitan antara "Ketuhanan Yang Maha Esa" dengan agama dalam konteks negara kesatuan Republik Indonesia yaitu:

“... sebagai dasar pertama, KeTuhanan Yang Maha Esa bukan saja meletakkan dasar moral diatas Negara dan Pemerintah, tetapi juga memastikan adanya kesatuan Nasional yang berasas keagamaan. Pengakuan sila pertama (KeTuhanan Yang Maha Esa) tidak dapat dipisah-pisahkan dengan Agama, karena adalah salah satu tiang pokok daripada perikehidupan manusia dan bagi bangsa Indonesia adalah juga sebagai sendi perikehidupan Negara dan unsur mutlak dalam usaha nation-building".

\footnotetext{
Jimly Assihiddiqie, 2010, Konstitusi \& Konstitusionalisme Indonesia, J akarta: Sinar Grafika, hlm. 81

3 Ridwan al-Makassary \& Chaidar S, Bamualim, "Dilema Aplikasi Syari'ah, Sekularisme dan Hak Asasi Manusia di Indonesia", J urnal Hukum Republica, Vol 3 No. 1 Tahun 2003, Fakultas Hukum Universitas Lancang Kuning Pekanbaru, hlm. 19-31
} 
Kemudian terkait dengan pengakuan tentang agama di Indonesia, Soekarno mengakui pertama-tama terhadap 6 agama yaitu Islam, Kristen, Katolik, Hindu, Budha dan khong $\mathrm{Cu}$ (Confusius). Namun pada ketentuan berikutnya juga menegaskan bahwa tidak ada pelarangan terhadap agama-agama lain seperti Yahudi, Zarasustrian, Shinto, dan Taoism. Sebaliknya, Prinsip "Ketuhanan Yang Maha Esa" justru menjadi senjata untuk mengawasi dan membatasi keyakinan-keyakinan tradisional nusantara karena dianggap "tidak sehat" dan dapat merusak agama sehingga negara perlu mengatur dan mengarahkannya. Padahal dalam kenyataannya yang sangat bertolak belakang dengan alasan dibuatnya penetapan presiden tersebut, justru masyarakat penghayat yang menjadi korban dari kelompok beragama dan oleh karenanya seharusnya merekalah yang mendapat perlindungan bukan justru dicurigai dan dibatasi aktifitasnya.

Lembaga peradilan di masa orde baru juga tidak independen karena dari segi administrasi sangat rentan dipengaruhi oleh Pemerintah karena secara organisatoris, administratif dan keuangan di bawah Kementerian Kehakiman yang mempunyai kewenangan di bidang penganggaran, kepegawaian dan penghukuman. Mahkamah Agung tidak mempunyai kewenangan untuk menguji Undang-Undang sehingga seluruh produk undang-undang yang bertentangan dengan Pasal 29 Konstitusi tidak bisa dilakukan revisi atau evaluasi. Hukum materiil yang diskriminatif dan lembaga peradilan yang tidak independen membuat masyarakat korban tidak membawa kasus mereka ke Pengadilan karena selain biaya yang mahal dan waktu yang panjang, putusan yang dihasilkan oleh pengadilan juga bisa diprediksi tidak akan berpihak kepada rasa keadilan mereka. Klaim hukum atas hak kebebasan beragama dan berkeyakinan yang sangat buruk di masa itu sungguh bertentangan dengan Preamble Konstitusi 1945 yang menyatakan bahwa "...membentuk Pemerintahan Indonesia yang melindungi segenap bangsa Indonesia...". Realitas di atas merupakan paradoks di era konstitusionalisasi hak atas kebe- basan beragama dan berkepercayaan karena di sisi lain hak tersebut justru dikhianati oleh peraturan perundang-undangan di bawahnya tanpa ada mekanisme evaluasi yang pasti, adil dan bermanfaat.

\section{Status preskriptif hak asasi manusia tetapi dengan penerapan yang ambigu}

Sebelum amandemen Kedua tahun 2000 maka Undang-Undang Dasar 1945 tidak pernah mencantumkan ketentuan secara eksplisit tentang hak asasi manusia meskipun ada beberapa ketentuan yang secara substantif mengatur tentang beberapa hak asasi manusia yang salah satunya adalah hak atas kebebasan beragama dan berkeyakinan di Pasal 29. Secara hukum, tidak ada kewajiban atributif bagi pemerintah untuk melembagakan hak asasi manusia karena yang pertama memang konstitusi tidak mengaturnya dan yang kedua adalah adanya anggapan bahwa hukum nasional secara substantif telah mengatur nilai-nilai hak asasi manusia.

Pemerintah Soeharto di masyarakat Internasional mempunyai citra buruk terkait dengan penegakan hak asasi manusia sehingga perlu bagi rezimnya untuk menyangkal hal tersebut sehingga pada tanggal 7 J uli 1993 Soeharto mengeluarkan Keputusan Presiden No. 50/1993 tentang Komisi Nasional Hak Asasi Manusia yang membuka gerbang bagi domestifikasi normanorma hak asasi manusia internasional. Soeharto mengangkat tokoh-tokoh nasional yang mempunyai reputasi tinggi sebagai komisioner komnasham untuk menjaga adanya resistensi dan pesimisme publik baik nasional maupun internasional. Meskipun tindakan tersebut pada prinsipnya untuk memperbaiki citra pemerintah tetapi secara hukum dan politik juga membawa konsekuensi akan masuknya norma-norma hak asasi manusia internasional ke dalalm wilayah domestik indonesia. Dalam kerangka konseptual hak asasi manusia "spiral model" maka Indonesia saat itu telah memasuki fase "tactical concessions" karena rezim sudah membuka diri akan hadirnya norma hak asasi manusia inter- 
nasional dalam kedaulatan hukumnya meskipun hanya pada tingkat perbaikan citra saja. ${ }^{4}$

Setelah era reformasi datang pada tahun 2008 yang ditandai dengan runtuhnya kekuasaan Orde Baru Soeharto dan digantikan dengan Presiden Habibie maka Indonesia memasuki era prescriptive status terkait dengan penormaan hak asasi manusia secara nasional. Pada tanggal 23 September 1999 Indonesia mengeluarkan Undang-undang No. 39/1999 tentang Hak Asasi Manusia yang pada pasal 4 menyatakan bahwa “...hak kebebasan pribadi, pikiran dan hati nurani, hak beragama... adalah hak asasi manusia yang tidak dapat dikurangi dalam keadaan apapun dan oleh siapapun". Pada Pasal 22 undang-undang ini juga menegaskan bahwa "Setiap orang bebas memeluk agamanya masingmasing dan untuk beribadat menurut agamanya dan kepercayaannya itu" dan "Negara menjamin kemerdekaan setiap orang memeluk agamanya masing-masing dan untuk beribadat menurut agamanya dan kepercayaannya itu". Setahun kemudian pada tanggal 18 Agustus 2000 Majelis Permusyawaratan Rakyat mengamandemen UUD 1945 dengan memasukkan beberapa ketentuan tentang hak atas kebebasan beragama dan berkeyakinan dalam Bab X tentang Hak Asasi Manusia sebagai berikut:

Pasal 28E:

(1) Setiap orang bebas memeluk agama dan beribadat menurut agamanya, memilih pendidikan dan pengajaran, memilih pekerjaan, memilih kewarganegaraan, memilih tempat tinggal di wilayah negara dan meninggalkannya, serta berhak kembali.

(2) Setiap orang berhak atas kebebasan meyakini kepercayaan, menyatakan pikiran dan sikap, sesuai dengan hati nuraninya.

(3) Setiap orang berhak atas kebebasan berserikat, berkumpul, dan mengeluarkan pendapat.

Pasal 28I:

(1) Hak untuk hidup, hak untuk tidak disiksa, hak kemerdekaan pikiran dan hati nurani, hak beragama, hak untuk tidak diperbudak, hak untuk diakui

Thomas Risse, et,al (ed), 2005, The Power of Human Rights: International Norms and Domestic Change, Cambridge: Cambridge University Press sebagai pribadi di hadapan hukum, dan hak untuk tidak dituntut atas dasar hukum yang berlaku surut adalah hak asasi manusia yang tidak dapat dikurangi dalam keadaan apa pun.

(2) Setiap orang berhak bebas dari perlakuan yang bersifat diskriminatif atas dasar apa pun dan berhak mendapatkan perlindungan terhadap perlakuan yang bersifat diskriminatif itu.

Preskripsi Konstitusi tentang hak asasi manusia khususnya hak atas kebebasan beragama dan berkepercayaan secara kelembagaan juga diperkuat dengan diperkenalkannya Mahkamah Konstitusi dalam sistem ketatanegaraan Indonesia yang berwenang menguji seluruh undang-undang terhadap undang-undang dasar termasuk undang-undang yang dikeluarkan sebelum dilakukannya amandemen.

Perlindungan Hak Asasi Manusia tidak saja diikhtiarkan kepada hukum materiil tetapi juga pada hukum formalnya yaitu dengan dikeluarkannya Undang-Undang Nomor 26 Tahun 2000 tentang Pengadilan Hak Asasi Manusia yang memberikan upaya perlindungan kepada kelompok agama tertentu dari kejahatan terhadap kemanusian dan pelanggaran berat hak asasi manusia. Tidak cukup sampai disitu, pada tahun 2005 Indonesia meratifikasi dua kovenan pokok hak asasi manusia yaitu ICESCR dan ICCPR masing-masing dengan Undang-Undang No. 11 dan 12 Tahun 2005. Dengan demikian maka Indonesia secara hukum terikat dalam penegakan ketentuan Pasal 18 ICCPR yang menyatakan bahwa:

(1) Everyone shall have the right to freedom of thought, conscience and religion. This right shall include freedom to have or to adopt a religion or belief of his choice, and freedom, either individually or in community with others and in public or private, to manifest his religion or belief in worship, observance, practice and teaching. 2. No one shall be subject to coercion which would impair his freedom to have or to adopt a religion or belief of his choice.

(2) Freedom to manifest one's religion or beliefs may be subject only to such 
limitations as are prescribed by law and are necessary to protect public safety, order, health, or morals or the fundamental rights and freedoms of others.

(3) The States Parties to the present Covenant undertake to have respect for the liberty of parents and, when applicable, legal guardians to ensure the religious and moral education of their children in conformity with their own convictions.

Todung Mulya Lubis melihat situasi yang melingkupi lahirnya status preskripsi hak asasi manusia tersebut di atas sebagai enlightened construction, meskipun di sisi lain muncul juga kebutuhan untuk melakukan pengawalan dan pengawasan terhadap pelaksanaan dan perjalanan ke depannya ${ }^{5}$.

Melimpahnya norma-norma hukum hak asasi manusia dalam sistem hukum nasional Indonesia menandai babak baru dalam penegakan hak asasi manusia dan seharusnya lebih menjajikan dibandingkan dengan ketika belum adanya landasan hukum. ${ }^{6}$ Apalagi, dalam konstitusi hasil amandemen ditegaskan bahwa Indonesia merupakan negara hukum dimana tata kelola negara harus didasarkan atas hukum dan bukan kekuasaan belaka (rechtstaat). Menjadi pertanyaan berikutnya adalah apakah pencapaian tujuan hukum akan selalu mempunyai hubungan lurus dengan melimpahnya norma hukum yang mengaturnya? Pertanyaan tentang bagaimana cara melakukan harmonisasi kehidupan antara umat beragama yang damai, saling percaya dan berkeadilan selalu menjadi pertanyaan dalam realitas pluralisme keberagamaan dan berkepercayaan di Indonesia. ${ }^{7}$ Selain itu ada sebuah simpulan penelitian yang menarik untuk disitir yaitu:

5 Todung Mulya Lubis, "Menegakkan Hak Asasi Manusia, Menggugat Diskriminasi", J urnal Hukum dan Pembangunan Vol 39 No. 1 Tahun 2009, Fakultas Hukum Universitas Indonesia, hlm. 58-73

6 Albert Hasibuan, "Politik Hak Asasi Manusia (HAM) dan UUD 1945", J urnal Law Review Vol VIII No. 1 J uli 2008, Fakultas Hukum Universitas Pelita Harapan Jakarta, hlm. 43-62

Krispurwana, "Telesphorus, Dialog Antaragama dan Tantangan bagi Perdamaian serta Keadilan", J urnal Diskursus Vol 6 No. 1 April 2007, Jakarta: Sekolah Tinggi Filsafat Driyakarya, hlm. 85-101

\begin{abstract}
"Reconsidering the question of whether we should recommence the process of producing a global legal instrument on the freedom of religion or belief might be a very good place to start. This would roll back the essentially negative approaches of recent years and champion a more positive vision of what religious freedom has to offer" 8
\end{abstract}

Pada tanggal 17 Januari 2000 Presiden $\mathrm{KH}$. Abdurrahman Wahid memulihkan kembali hak-hak kegamaan, kepercayaan dan adat istiadat masyarakat keturunan China di Indonesia yang selama ini mengalami diskriminasi karena tidak bisa menikmati hak-hak terkait kebebasan beribadah, berekspresi dan berasosiasi berdasarkan agama dan keyakinan mereka karena dianggap akan berdampak buruk terhadap tatanan sosial hanya karena mereka bukan keturunan pribumi dengan mengeluarkan Keputusan Presiden No.6 Tahun 2000 tentang Pencabutan Instruksi Presiden No.14 Tahun 1967 tentang Agama, Kepercayaan, dan Adat Istiadat Cina.

Tercapainya tujuan hukum dalam masyarakat seperti kepastian, keadilan, dan kemanfaatan kemudian menjadi pertanyaan besar ketika konflik agama masih terus terjadi. Bahkan, dari segi pelaku juga mengalami transisi yaitu kalau dulu semata-semata diskriminasi dilakukan oleh aparatur negara tetapi perkembangannya sekarang pelanggaran justru dilakukan juga oleh kelompok masyarakat. Kelompok Ahmadiyah pada jaman Soeharto mendapat pengakuan yang sangat kuat dimana pada setiap musyawarah nasional selalu dihadiri oleh pejabat tinggi kementerian agama, namun sekarang kelompok ini mendapat serangan dari kelompok agama lain dengan tanpa mendapat perlindungan yang memadai dari negara. Demikian juga dengan penyerangan terhadap gereja-gereja sebelum era reformasi hampir tidak pernah terjadi meskipun di sisi lain ij in mendirikan gereja juga sangat sulit hingga sampai sekarang. Hukum dalam situasi seperti itu merupakan sebuah problem dan alat untuk setidak-tidaknya

\footnotetext{
Malcolm Evans, "Advancing Freedom of Religion or Belief: Agendas for Change", Oxford Journal of Law and Religion, doi: 10,1093/ ojlr/ rwr002, 2011, hlm. 110
} 
menjadi pembenar bagi pelanggaran hak asasi manusia.

Hukum yang sangat rapuh dalam penegakannya menjadikan awal dari sebuah tuntutan untuk melakukan evaluasi normatif melalui lembaga peradilan terhadap peraturan perundang-undangan yang dalam praktiknya digunakan sebagai alat pembenar untuk melakukan kekerasan berbasis agama. Sebab tidak jarang para pelaku kekerasan memanfaatkan celah peraturan perundang-undangan yang memang dapat digunakan sebagai alat untuk menghindari tuntutan pidana disamping juga masih lemahnya aparat kepolisian di lapangan untuk menggunakan celah hukum guna melindungi korban kekerasan karena alasan teknis seperti kalah jumlah dibanding massa perusak maupun pelaku kekerasan. Aspek hukum sebenarnya bukan satu-satunya akar permasalahan mengapa kekerasan berbasis agama terjadi namun demikian akan sulit untuk memisahkan setiap kasus kekerasan jika tidak menghubungkannya dengan peraturan perundang-undangan karena pada akhirnya semua proses penyelesaian akan bertemu dalam ruang dan ranah hukum seperti di Kepolisian dan Pengadilan. Sehingga, pengujian terhadap peraturan perundang-undangan yang tidak lagi relevan dengan semangat penegakan hak asasi manusia merupakan hal yang sangat penting pada saat kekerasan ber-basis agama masih sering terjadi.

Pengujian peraturan perundang-undangan pada era reformasi telah mempunyai sistem yang mapan dengan terbentuknya Mahkamah Konstitusi. Penggantian hukum yang tidak relevan lagi dengan norma-norma hak asasi manusia dalam konstitusi memang bisa dilakukan dengan pembuatan hukum yang baru melalui lembaga legislatif sehingga berlaku prinsip Lex posteori derogat legi priori. Akan tetapi pilihan tersebut kurang menjanjikan di tengah buruknya reputasi dan performa lembaga legislatif. Dari segi hukum, pilihan terbaik dari situasi yang terburuk adalah dengan melakukan pengujian atau judiciil review terhadap peraturan perundang-undangan yang sering digunakan sebagai alasan pembenar bagi tindak kekerasan dan intoleransi ke Mahkamah Konstitusi. UU
No. 1/ PNPS Tahun 1965 tentang Pencegahan Penyalahgunaan dan/ atau Penodaan Agama merupakan salah satu peraturan perundang-undangan yang sering digunakan oleh para pelaku kekerasan berbasis agama sebagai alasan pembenar. Norma inti dari UU No. 1/PNPS Tahun 1965 tentang Pencegahan Penyalahgunaan dan/ atau Penodaan Agama sebagaimana tercantum pada Pasal 1 sebagai berikut:

"Setiap orang dilarang dengan sengaja di muka umum menceritakan, menganjurkan atau mengusahakan dukungan umum, untuk melakukan penafsiran tentang sesuatu agama yang dianut di Indonesia atau melakukan kegiatan-kegiatan keagamaan yang menyerupai kegiatan-kegiatan keagamaan dari agama itu, penafsiran dan kegiatan mana menyimpang dari pokok-pokok ajaran agama itu"

Untuk memberikan kekuatan terhadap penegakan norma tersebut maka di pasal lain dari undang-undang tersebut diatur ketentuan pidananya termasuk pidana penjara 5 (lima) tahun bagi yang melanggarnya. Kemudian secara kelembagaan negara maka Undang-Undang ini memberikan kewenangan kepada Presiden meIalui menteri agama, menteri dalam negeri dan jaksa agung untuk melakukan pengawasan aktifitas, pembubaran, hingga pemidanaan terhadap kelompok-kelompok yang dianggap menyimpang dari ajaran agama mainstream yang diakui negara. Sebagaimana telah diteliti juga sebelumnya bahwa bahwa undang-undang tersebut sangat problematis untuk diterapkan pada saat ini ketika Indonesia secara hukum sudah terikat dengan norma-norma hak asasi manusia baik pada tingkat nasional maupun internasional $^{9}$. Meskipun pada awalnya undang-undang tersebut ingin membatasi munculnya aliran kepercayaan yang bertentangan dengan nilainilai keagamaan tetapi dalam perkembangannya sulit terkontrol dan justru digunakan untuk memberangus pandangan kritis terhadap praktik-praktik keagamaan. Sangat jarang sekali, untuk mengatakan tidak ada, penegakan norma

Frans Hendra Winata, "Agama Tidak Memerlukan Pengakuan Negara Secara Resmi dan Diatur Hukum", J urnal Law Review Vol VIII No. 1 J uli 2008, Jakarta: Fakultas Hukum Universitas Pelita Harapan, hlm. 84-94 
undang-undang ini dilaksanakan melalui tata acara peradilan yang sah dan proses yang damai melainkan yang terjadi adalah peradilan jalanan yang berdarah-darah.

\section{Kesenjangan antara Penafsiran dan Penerap- an Akibat Politik Pengabaian}

Pada tanggal 28 Oktober 2009 para pegiat hak asasi manusia Indonesia, salah satunya mantan Presiden Abdurrahman Wahid, mengajukan uji materiil terhadap UU No.1/ PNPS 1965 ke Mahkamah Konstitusi dalam rangka mempertegas hak konstitusional umat minoritas atas kebebasan beragama dan berkepercayaan yang selama ini termarginalkan. Senjata normatif yang digunakan cukup memadai dan sangat kokoh secara hukum, baik nasional maupun internasional. Berhadapan dengan para pemohon dalam perdebatan di persidangan adalah saksisaksi dari Pemerintah, DPR, dan beberapa organisasi masyarakat keagamaan terutama Islam yang notabene adalah agama-agama yang besar dan diakui secara administratif oleh negara. Secara politis, mereka yang melawan pemohon adalah organisasi massa yang mempunyai anggota berjumlah jutaan bahkan menjadi pemegang suara mayoritas dalam setiap pemilihan umum. Fakta yang menarik adalah bersatunya antara beberapa organisasi Islam yang dalam keseharian mempunyai banyak perbedaan dalam banyak hal, sebagai contohadalah NU, Muhammadiyah, Hizbut Tahrir, dan FPI. Para pemohon dalam proses judicial review seolaholah dianggap sebagai common enemy bagi seluruh ormas Islam sehingga mereka bersatu untuk tetap mempertahankan UU No. 1/PNPS 1965. Sejak awal, para pemohon baik di luar maupun di dalam pengadilan selalu dianggap sebagai sekelompok orang dan LSM yang ingin mengikis nilai-nilai religiusitas masyarakat Indonesia dan ingin menyebarkan paham-paham liberalisme, individualisme, dan sekularisme sehingga harus dilawan bahkan dengan cara kekerasan sekalipun. Dalam konteks seperti itulah akhirnya Mahkamah Konstitusi mengeluarkan Putusan Nomor 140/ PUU-VII/ 2009 yang menyatakan menolak seluruh permohonan para pemohon dan dengan demikian maka Undang-Undang
No. 1/ PNPS Tahun 1965 tetap berlaku dan tanpa ada perubahan sedikitpun.

Salah satu alasan kuat Mahkamah Konstitusi untuk tetap mempertahankan eksistensi Undang-Undang No.1/ PNPS Tahun 1965 adalah adanya kewenangan negara untuk membatasai pelaksanaan hak atas kebebasan beragama dan berkeyakain dengan mendasarkan secara hukum kepada ketentuan-ketentuan peraturan perundang-undangan sebagai berikut. Pertama, Pasal 28J UUD 1945 ayat (1) dan (2); kedua, Pasal 18 Undang-Undang No.12 Tahun 2005; dan ketiga, Pasal 70 Undang-Undang Hak Asasi Manusia.

Apabila diringkas maka alasan pembatasan yang menjadi dasar hukum putusan pengadilan adalah sebagai berikut. Pertama, pembatasan dibuat dengan undang-undang dan peraturan pelaksananya; kedua, sebagai bentuk penghormatan atas hak dan kebebasan orang lain; ketiga, moral; keempat, nilai-nilai agama; kelima, keamanan; keenam, kesehatan; ketujuh, ketertiban umum; dan kedelapan, masyarakat yang demokratis.

Keunikan dari alasan pembatasan yang digunakan dalam sistem hukum di Indonesia jika dibandingkan dengan ketentuan-ketentuan internasional adalah digunakannya nilai-nilai agama sebagai alasan untuk membatasi penikmatan hak asasi manusia khususnya hak kebebasan beragama dan berkeyakinan. Persoalan muncul terutama dalam kasus penikmatan hak atas kebebasan beragama dan berkeyakinan yang dimiliki oleh kelompok minoritas dimana agama dan kepercayaan mereka pasti berbeda dengan kelompok mainstream atau mayoritas sehingga dalam proses pembatasan tentu yang digunakan adalah standart kelompok mayoritas. Dalam situasi tersebut maka akan cenderung untuk menghasilkan perlakuan negara yang diskri-minatif terhadap kelompok minoritas apalagi bagi Indonesia yang menganut sistem negara dimana banyak kebijakan publik ditentukan oleh suara mayoritas (majority voices). Dalam potensi masalah seperti ini sebenarnya reputasi mahkamah konstitusi diuji sejauh mana mereka bisa bersikap adil bagi semua golongan untuk 
mewujudkan rasa keadilan sebagai tujuan akhir mengapa hukum itu dibentuk.

Apabila dilihat dari pertimbangan putusan yang dibuat oleh Mahkamah Konstitusi maka terlihat bahwa penggunaan dasar hukum kewenangan negara dalam melakukan pembatasan terhadap pelaksanaan hak kebebasan beragama dan berkeyakinan tidak diikuti dengan alasanalasan yang cukup kuat sebagaimana telah dikenal dalam hukum internasional maupun pendapat para ahli di bidang hak asasi manusia. Sejak awal ditegaskan oleh para hakim bahwa penafsiran terhadap pelaksanaan hak asasi manusia harus diletakan dalam kerangka sikap pandang bangsa Indonesia yang tidak tunduk kepada paham-paham manapun seperti liberalisme, sosialisme, maupun individualisme. Dalam putusannya, para hakim tidak menjelaskan lebih lanjut tentang paham-paham tersebut dan apa kaitannya dengan perkara yang ditangani. Hakim seolah-olah ingin menjauh dari perkembangan hak asasi manusia internasional dengan berlindung di balik partikularitas domestik Indonesia. Dalam pertimbangan putusannya hakim memperkenalkan istilah jalan tengah dalam menyikapi konteks universalitas hak atas kebebasan beragama sebagai bagian dari hak asasi manusia dengan realitas internal bangsa Indonesia dalam hal ini adalah nilai-nilai agama Islam. Hal ini memang sudah menjadi bagian dari kecendurangan umum sejak lama bagaimana implementasi atas tafsir hak asasi manusia di negara-negara Islam. ${ }^{10}$

Mahkamah Konstitusi dalam kasus ini telah membuat sebuah Putusan yang tidak memberikan apresiasi terhadap perkembangan hak asasi manusia di Indonesia yang secara hukum telah memiliki landasan sangat kuat dan secara praktis memang dibutuhkan oleh masyarakat terutama kelompok beragama/berkeyakinan minoritas. ${ }^{11}$ Putusan tersebut juga telah menyederhanakan terhadap problem hak atas ke-

10 Mohamad Hudaeri, "Islam dan Hak Asasi Manusia: Respon Intelektual Muslim", J urnal Al-Qalam Vol 24 No. 3 Tahun 2007, PPPM IAIN Sultan Maulana Hasannudin, hlm. 364-386

11 Muhammad As'ad, "Ahmadiyah and the Freedom of Religion in Indonesia", J ournal of Indonesian Islam, Vol 03 (02) Desember 2009, Program Pascasarjana IAIN Sunan Ampel Surabaya, hlm. 390-413 bebasan beragama dan berkeyakinan dengan cara memutus mata rantai keterkaitan antara pemberlakuan undang-undangan penodaan agama dengan pelanggaran hak konstitusional atas kebebasan beragamaan berkeyakinan yang dalam tataran praktis sudah sangat memprihatinkan. ${ }^{12}$

Tetap diberlakukannya undang-undang tersebut menimbulkan hal buruk yang akan tetap terjadi adalah terbukanya ruang intervensi negara yang terlalu jauh dalam kehidupan aga$\mathrm{ma}$ / kepercayaan warga negara. Intervensi ini sering diterapkan dengan cara-cara yang bias terkait hubungan antara kelompok beragama/ berkeyakinan mayoritas dan minoritas sehingga selalu merugikan mereka yang menjadi bagian dari kelompok minoritas. Padahal dalam undang-undang hak asasi manusia dan konstitusi ditegaskan bahwa negara melalui organ-organnya mempunyai kewajiban untuk melakukan tindakan affirmative action bagi kelompok rentan yang di dalamnya termasuk kelompok aga$\mathrm{ma/}$ keyakinan minrotas.

Selain itu, apabila dilihat dari pertimbangan putusan maka akan nampak bahwa para hakim tidak memberikan sumbangan yang cukup berarti terhadap tafsir norma-norma konstitusi terkait penikmatan hak atas kebebasan beragama dan berkeyakinan. Para saksi ahli telah memberikan masukan-masukan yang cukup komprehensif terkait dengan perkembangan praktek-praktek pengaturan hak atas kebebasan beragama dan berkeyakinan, akan tetapi banyak dari pertimbangan tersebut tidak menjadi pertimbangan hakim dalam mengambil putusan. Hakim lebih berfokus kepada asumsi bahwa apabila undang-undang tentang penodaan agama tidak ada maka akan terjadi chaos dalam masyarakat karena akan timbul konflik horizontal antar umat beragama yang bersumber dari ketidakterimaan kelompok agama atas tafsir kelompok lain yang dianggap menodai agama mereka. Menjadi pertanyaan berikutnya adalah apakah tafsir Mahkamah Konstitusi ter-

\footnotetext{
12 Margiyono, et al, 2011, Bukan J al an Tengah, Eksaminasi Publik Putusan Mahkamah Konstitusi terhadap UndangUndang No, 1 Tahun 1965 tentang Penyalahgunaan dan/ atau Penodaan Agama, J akarta: ILRC
} 
sebut mempunyai dasar yang kuat dalam kehidupan nyata? ataukah tafsir tersebut merupakan bentuk nyata dominasi kelompok mayoritas atas kelompok minoritas? dan apakah memang terbukti jika undang-undang tersebut eksis maka akan terjadi tertib sosial sehingga penikmatan hak atas kebebasan beragama dan berkeyakinan akan tercapai? Untuk menjawab hal itu semua maka harus dilihat situasi nyata dalam masyarakat pasca dikeluarkannya putusan tersebut. Kesetaraan hak bagi semua penganut agama dalam konstruksi hukum dan sosial memang sangat kompleks apalagi terkait dengan overlapping norma dan nilai-nilai dalam masyarakat. Terjebaknya hakim Mahkamah Konstitusi mungkin tergambar juga dari simpulan yang dibuat oleh Danchin terkait diskusinya tentang esensi "manusia" dalam hak asasi manusia dalam perspektif klaim agama dan budaya sebagai berikut:

"Of course, any such claims raise complex and difficult conflicts between equality norms on the one hand, and religious and cultural freedom norms on the other. A value pluralist approach to such questions opens the possibility of new forms of the hermeneutic circle and thus diverse forms of fusion of horizons. This, in turn, opens the way to a less dogmatic and binary account of reason and religion by viewing both as human institutions and social practices requiring modes of justification and accountability. J ust as is the case with the doctrine of substantive neutrality, this requires the constant search for forms of accommodation, mutual understanding, and overlapping consen-sus between actual religious communities and the normative claims of rights discourse understood in value pluralist and philosophically hermeneutic terms. In order for this to occur, however, the primary obstacle, the inability of Western rights theorists to see their culture as one amongst others, must be surpassed". ${ }^{13}$

Situasi ini telah menguji betapa pluralitas keberagamaan yang dianut oleh bangsa-bangsa

13 Peter G Danchin, "Who is the "Human" in Human Rights? The Claims of Culture and Religion", Maryland Journal of International Law, Vol 24 No. 99 Tahun 2009, hlm. 99-124 yang ada di Indonesia secara filosofis mengalami ujian yang cukup berat terutama bagi umat minoritas. Kekuasaan negara yang masuk dalam ranah keberagamaan telah menyempitkan "ruang teologis bebas kekuasaan" sehingga berakibat kepada terancamnya budaya baru yang lebih manusiawi, berperadaban, berkerukunan, serta kebhinekaan dalam ikatan keadaban (genuine engagment of diversities within the bonds of civility). ${ }^{14}$

Kasus-kasus pelanggaran hak kebebasan beragama dan berkeyakinan tahun 2010, jika dilihat dari segi komposisi korban terdapat perincian yaitu $35 \%$ adalah komunitas yang di anggap sesat sedangkan sisanya merupakan korban yang bersifat individu, properti, dan rumah ibadah. Sedangkan pelaku pelangaran terbesar adalah institusi Kepolisian (37\%) diikuti dengan lembaga Pemerintahan Daerah (36\%) yang sebenarnya secara geografis wilayah kerja kedua lembaga tersebut berada sama-sama di tingkat daerah. Lokasi terbesar dari pelanggaran hak atas kebebasan beragama dan berkeyakinan adalah di Pulau Jawa khususnya Propinsi Jawa Barat dan Jawa Timur yang mayoritas penduduknya beragama Islam. Sedangkan di luar Pulau Jawa sangat sedikit sekali dijumpai pelanggaran hak. ${ }^{15}$ Besarnya prosentase pelanggaran hak yang terjadi di daerah merupakan indikasi betapa telah terjadi ketidaksambungan antara harapan dipertahankannya UU No. 1/ PNPS 1965 menurut tafsir Mahkamah Konstitusi dengan pemahaman yang diterapkan oleh aparatur negara di tingkat bawah. Sangat menarik dalam hal ini untuk melihat salah satu produk kebijakan administratif Pemerintah Provinsi Jawa Timur dalam menangani kelompok minoritas Jemaah Ahmadiyah yaitu Surat Keputusan Gubernur Nomor 188/94/ KPTS/ 013/2011 tentang Larangan Aktifitas J emaat Ahmadiyah Indonesia (J Al) di J awa Timur

Keputusan tersebut pada bentuk formalnya bertujuan untuk menjaga ketertiban umum

14 Hajiannor, "Pluralisme Agama dalam Perspektif Filsafat Perennial", Jurnal Ittihad Vol 8 No. 13 April 2010, Kopertis Wilayah XI Kalimantan, hlm. 33-44

15 The Wahid Institute, 2010, Laporan Kebebasan Beragama/Berkeyakinan dan Toleransi 2010, J akarta: The Wahid Institute 
dan keamanan nasional karena secara hukum masalah agama merupakan domain pemerintah pusat sehingga harus ada topeng untuk membuat kebijakan administratif tersebut menjadi sah secara hukum (formal). Tetapi dalam kenyataan dan substansinya justru kebijakan tersebut telah masuk ke dalam wilayah pembatasan akan hak atas kebebasan beragama dan berkeyakinan. Hal itu karena pada isi dari Keputusan tersebut yaitu pada ketetapan kedua menyatakan bahwa terhadap kelompok minoritas Ahmadiyah diberlakukan ketentuan berupa: pertama, menyebarkan aj aran Ahmadiyah secara lisan, tulisan maupun elektronik; kedua, memasang papan nama organisasi di tempat umum; ketiga, memasang identitas J Al pada tempat-tempat ibadah dan lembaga pendidikannya; dan keempat, menggunakan atribut J Al dalam segala bentuknya.

Apabila dilihat pada pertimbangan Keputusan Gubernur maka jelaslah bahwa demi "Ketuhanan Yang Maha Esa" sesuai dengan norma konstitusi dan kemudian ditegakan dengan UU No. 1/ PNPS Tahun 1965 tentang Pencegahan Penodaan dan/atau Penyalahgunaan Agama maka pemerintah daerah mempunyai pijakan hukum untuk melakukan diskriminasi terhadap kaum minoritas dalam menikmati hakhak atas kebebasan bergama dan berkeyakinannya. Sehingga sangat jelas bahwa surat keputusan gubernur tersebut mengandung paradok norma sehingga dapat dikategorikan keputusan yang cacat hukum sehingga secara hukum tidak mengikat. Sebenarnya, apakah memang perlu untuk membuat sebuah keputusan administratif yang sah secara hukum oleh gubernur dalam menghadapi kasus kekerasan beragama? Apakah validitas hukum suatu kebijakan administratif menyangkut hak atas kebebasan beragama dan berkeyakinan sangat penting dibandingkan harus menghadapi tekanan oleh kelompok mayoritas? Apakah pengadilan mempunyai kuasa atas situasi yang melemahkan penikmatan hak atas kebebasan beragama dan berkeyakinan oleh kelompok minoritas?

Kebijakan administratif gubernur hanya menjadi instrumen hukum kelompok mayoritas untuk memberikan tekanan terhadap kelompok minoritas dengan mengabaikan norma-norma konstitusi dan hak asasi manusia. Kelompokkelompok mayoritas yang menjadi faktor pendorong gubernur mengeluarkan keputuan tersebut meliputi organisasi keagamaan, partai politik, perguruan tinggi, organisasi mahasiswa. Logika normatif hukum sudah tidak lagi menjadi pertimbangan penting karena faktanya terjadi banyak paradok dan kontradiksi di dalam keputusan gubernur tersebut akan tetapi pada kenyataannya peraturan tersebut sangat efektif untuk menekan kelompok minoritas. Sulit bagi mereka yang menjadi korban atas kebijakan administratif tersebut untuk melakukan banding ke pengadilan karena kepercayaan masyarakat kepada lembaga pengadilan sangat rendah apalagi dengan adanya tafsir mahkamah konstitusi sebelumnya membuat masyarakat semakin pesimis dengan kapasitas pengadilan untuk menangani kasus-kasus hak atas kebebasan beragama. Resiko keamanan juga menjadi pertimbangan penting bagi para aktivis kebebasan beragama dan berkeyakian ketika akan membawa kasus ini ke pengadilan karena lemahnya perlindungan negara terhadap aktifitas ini serta tidak jarang terjadi intimidasi dari kelompok radikal yang mengancam keselamatan mereka.

Setelah satu propinsi berhasil menekan kelompok minoritas dengan kebijakan administratifnya maka kemudian diikuti oleh propinsi lain di Indonesia dengan variasi formalitas hukum yang tidak jauh berbeda. Instrumen kebijakan hukum administrasi biasanya berupa peraturan gubernur, keputusan bupati, surat edaran gubernur dan seterusnya yang sebenarnya secara fungsi dan isi relatif sama yaitu memberi pembatasan terhadap kelompok agama minoritas. Pada setiap peraturan hukum tersebut satu hal yang selalu ada dan sama dalam pertimbangan hukumnya yaitu digunakannya UU No. 1/ PNPS Tahun 1965 sebagai dasar hukum untuk membatasi kebebasan beragama kelompok agama atau keyakinan yang dianggap sesat. Dari pola ini jelas terlihat bahwa apa yang telah diputuskan oleh Mahkamah Konstitusi memang benar-benar menjadi alat legitimasi hukum bagi lembaga-lembaga pemerintahan di daerah untuk melakukan diskriminasi terhadap kelompok 
minoritas lepas dari apakah alasan hukumnya benar atau salah akan tetapi secara praktikal kebijakan tersebut memang sangat efektif. Fakta di atas mempertegas betapa perubahan hukum secara normatif dalam pelaksanaannya akan sangat ditentukan juga oleh kapasitas para pengemban hukum seperti hakim dan aparatur pemerintahan. ${ }^{16}$ Danchin dalam penelitiannya tentang kebebasan beragama dalam konteks hukum internasional juga menggambarkan adanya ketegangan antara kelompok yang proliberalisme yang menekankan pada perlindungan individu dengan mereka yang menempatkan kepentingan umum atau komunal sebagai berikut:

The result is that today, international human rights law on freedom of religion and belief reflects the tension between these two "liberal" and "communitarian" strands of doctrinal history?one narrative expressing the Enlightenment commitment to individual freedom and moral autonomy, the other narrative expressing the counter Enlightenment concern for collective cultural and religious diversity. In this respect, the law both is a useful corrective to excessively individualistic approaches to the question of religious freedom and at the same time is open-textured and radically indeterminate in its provision for group-differentiated claims. These two clusters of norms merely reproduce the dilemmas we are grappling with within the structure of legal argument without providing any substantive means for the resolution of conflicts between rights in specific contexts. For the norm of freedom of religion or belief to have any meaning, it must therefore advance "external" or "objective" values that can only be generated through ongoing inter-subjective discourse and the search for consensus both within and between different nomian sovereign spheres of thick paideic meaning. ${ }^{17}$

16 Dyah Wijaningsih, "Perubahan Sosial dan Hukum (Dalam Ancangan dan Pemikiran)", J urnal Hukum Vol 14 No. 1 Januari 2004, Fakultas Hukum Universitas Islam Sultan Agung Semarang, hlm. 112-125

17 Peter G Danchin, "The Emergence and Structure of Religious Freedom in International Law", Journal of Law and Religion, Vol 23 No. 2 2007/2008, hlm. 455534
Kebebasan beragama dan berkeyakinan sebagai bagian dari hak asasi manusia masih menyimpan banyak permasalahan terutama bagi kelompok minoritas. Pengakuan hukum mulai dari konstitusi sampai ke hukum administrasi belum secara otomatis menjamin penegakannya. Fenomena ini bukan hanya terjadi di Indonesia melainkan hampir di seluruh dunia. ${ }^{18}$

\section{Penutup}

Sampai saat ini Indonesia mempunyai prestasi yang sangat baik dalam hal penerimaan secara preskriptif terhadap norma-norma hak asasi manusia internasional yang diwujudkan dalam pengaturan di dalam sistem hukumnya mulai dari Konstitusi hingga ke penjabarannya di tingkat regulasi administratif. Hal tersebut tidak lepas dari pengaruh tekanan masyarakat internasional yang saat ini tengah mengupayakan dengan kuatnya proses domestifikasi norma-norma hak asasi manusia. Di sisi lain, telah terjadi resistensi baik secara terbuka maupun tertutup oleh lembaga-lembaga negara maupun organ-organ administrasi terhadap norma-norma hak asasi manusia terutama menyangkut masalah hak atas kebebasan beragama dan berkeyakinan bagi kelompok minoritas. Hal ini nampak dari munculnya paradok norma yang ada dalam keputusan lembaga peradilan mau pun organ pemerintahan menyangkut kasuskasus kebebasan beragama dan berkeyakinan.

Reformasi konstitusi yang mengikuti proses perubahan politik pasca runtuhnya rezim otoriter Soeharto yang pada awalnya ditujukan sebagai pintu masuk perbaikan hukum nasional terutama mengenai penegakan hak asasi manusia ternyata juga terjebak dalam situasi di atas. Produk-produk hukum lama yang diskriminatif terhadap pelaksanaan hak atas kebebasan beragama dan berkeyakinan ternyata masih dipertahankan terutama melalui tafsir operasionalnya seiring dengan majority exceptionalism yang ternyata juga menjangkau struktur dan politik hukum Mahkamah Konstitusi. Konse-

18 Bielefeldt, Heiner, "Freedom of Religion or Belief-A Human Right under Pressure", Oxford Journal of Law and Religion, doi: 10,1093/ oj Ire/rwr018, 2012, hlm. 121 
kuensinya, tinda-kan-tindakan pelanggaran hak atas kebebasan beragama dan berkeyakinan kelompok minoritas masih secara konsisten terjadi dan menyebar ke daerah-daerah karena telah mendapatkan legitimasi hukum dan kekuasaan negara.

Pembatasan hukum terhadap pelaksanaan hak kebebasan beragama dan berkeyakinan terutama bagi kelompok minoritas melalui kebijakan administrasi meskipun bias dan tidak valid menurut prinsip-prinsip umum hak asasi manusia tetapi dalam tataran praktis berjalan sangat efektif. Hal tersebut terjadi karena sistem politik dan hukum sangat kondusif untuk selalu menguatkan kepentingan mayoritas tanpa adanya mekanisme pengujian lembaga peradilan yang fair dan bebas dari interfensi politik dan tekanan publik.

Mencermati hal diatas, maka nyatalah bahwa penegakan hak asasi manusia ternyata akan sangat tergantung kepada konstruksi politik hukum nasional dan regional suatu negara. Penormaan hak asasi manusia yang ideal dalam peraturan perundang-undangan akan hanya sebatas di atas kertas apabila para stakeholders seperti pemerintah pusat, lembaga peradilan, lembaga birokrasi, masyarakat politik, dan civil society masih jauh pemahamannya terhadap norma itu sendiri. Bagaimanpun, hak atas kebebasan beragama dan berkeyakinan yang bersumber dari norma-norma internasional akan mengalami kontestasi dengan nilainilai agama yang partikular dari negara dimana hak tersebut akan diterapkan, terutama agama yang dianut oleh penduduk mayoritas. Salah satu cara yang dapat pilih sebagai alternatif soIusi dalam menghadapi masalah tersebut adalah dengan secara konsisten melakukan proses sosialisasi norma-norma hak asasi manusia yang universal ke semua pemangku otoritas negara dan kelompok masyarakat sehingga terwujud perilaku yang konsisten. ${ }^{19}$ Secara praktikal yang menjadi proses penting dalam pilihan tersebut adalah dengan melakukan pengembangan wa-

19 Achmad Busro, "Penegakan Hak Asasi Manusia dalam Hukum pada Era Globalisasi yang Multidimensional", Jurnal Masalah-Masalah Hukum Fakultas Hukum Universitas Diponegoro Semarang, Vol 37 (3) Tahun 2008, hlm 174-180 cana hak asasi manusia terutama hak atas kebebasan beragama dan berkeyakinan secara terbuka, obyektif, dan bebas dari prasangka (prejudice) dalam lingkaran-lingkaran kemasyarakatan umat Muslim di Indonesia sehingga mereka sebagai umat mayoritas akan menjadi pilar yang kokoh untuk mewujudkan toleransi dan kerukunan antar umat beragama. Dengan demikian maka politik hukum yang tercipta dalam ranah publik dengan sendirinya akan dapat memberikan dukungan terhadap penikmatan hak atas kebebasan beragama dan berkeyakinan terutama bagi kelompok minoritas. Apabila hak atas kebebasan beragama dan berkeyakinan telah terpenuhi dan terlindungi maka berdasarkan sebuah penelitian akan meningkat pula produktifitas sosial dan ekonomi masyarakat sebagaimana disimpulkan sebagai berikut:

The empirical data are clear on two points. First, religious freedom is part of the bundled commodity" of human freedoms that energize broader productive participation in civil society by all religious groups, which is conducive to the consolidation of democracy and to socioeconomic progress. Secondly, religious freedom reduces conflict and increases security by, among other things, removing grievances religious groups have toward governments and their fellow citizens. ${ }^{20}$

\section{Daftar Pustaka}

Al-Makassary, Ridwan \& Bamualim Chaidar S. “Dilema Aplikasi Syari'ah, Sekularisme dan Hak Asasi Manusia di Indonesia". J urnal Hukum Republica, Vol 3 No. 1 Tahun 2003. Fakultas Hukum Universitas Lancang Kuning Pekanbaru;

As'ad, Muhammad. "Ahmadiyah and the Freedom of Religion in Indonesia, J ournal of Indonesian Islam". Program Pascasarjana IAIN Sunan Ampel Surabaya, Vol 03 (02) Desember 2009;

Asshiddiqie, Jimly. 2010. Konstitusi dan Konstitusionalisme Indonesia. Jakarta: Sinar Grafika;

20 Brian J Grim, "Religious Freedom and Social Wellbeing: A Critical Appraisal", International Journal for Religious Freedom, Vol 2 (1) tahun 2009, hlm. 37-46 
Bielefeldt, Heiner. "Freedom of Religion or Belief-A Human Right under Pressure". Oxford J ournal of Law and Religion, doi: 10, 1093/ oj Ire/ rwr018, 2012;

Busro, Achmad. "Penegakan Hak Asasi Manusia dalam Hukum pada Era Globalisasi yang Multidimensional". J urnal Masalah-Masalah Hukum, Vol 37 No. 3 Tahun 2008 Fakultas Hukum Universitas Diponegoro Semarang;

Danchin, Peter G. "The Emergence and Structure of Religious Freedom in International Law". Journal of Law and Religion, Vol 23 No. 2 2007/ 2008;

"Who is the "Human" in Human Rights? The Claims of Culture and Religion". Maryland J ournal of Interna-tional Law, Vol 24 No. 99 2009;

Dwi, Agnes. "Solidaritas Bagi Kebebasan Beragama". J urnal Maarif, Vol 5 No. 2 Tahun 2010. Maarif Institute J akarta;

Evans, Malcolm. "Advancing Freedom of Religion or Belief: Agendas for Change". Oxford Journal of Law and Religion, doi: 10, 1093/ ojlr/ rwr002, 2011;

Grim, Brian J. "Religious Freedom and Social Well-being: A Critical Appraisal". International Journal for Religious Freedom, Vol 2 No. 1 2009;

Hajiannor. "Pluralisme Agama dalam Perspektif Filsafat Perennial". J urnal Ittihad, Vol 8 No. 13 April 2010. Kopertis Wilayah XI Kalimantan;

Hasibuan, Albert. "Politik Hak Asasi Manusia (HAM) dan UUD 1945". Jurnal Law Review, Vol VIII No. 1 Juli 2008. Fakultas Hukum Universitas Pelita Harapan Jakarta;
Hudaeri, Mohamad. "Islam dan Hak Asasi Manusia: Respon Intelektual Muslim". J urnal Al-Qalam, Vol 24 No. 3 Tahun 2007. PPPM IAIN Sultan Maulana Hasannudin;

Krispurwana. “Telesphorus, Dialog Antaragama dan Tantangan bagi Perdamaian serta Keadilan". J urnal Diskursus, Vol 6 No. 1 April 2007. Jakarta: Sekolah Tinggi Filsafat Driyakarya;

Lubis, Todung Mulya. "Menegakkan Hak Asasi Manusia, Menggugat Diskriminasi". J urnal Hukum dan Pembangunan, 39 No. 1 Tahun 2009. Fakultas Hukum Universitas Indonesia;

Margiyono, et al. 2011. Bukan Jalan Tengah, Eksaminasi Publik Putusan Mahkamah Konstitusi terhadap Undang-Undang No,1 Tahun 1965 tentang Penyalahgunaan dan/atau Penodaan Agama. Jakarta: ILRC;

Risse, Thomas, et,al (ed). 2005. The Power of Human Rights: International Norms and Domestic Change. Cambridge: Cambridge University Press;

The Wahid Institute. 2010. Laporan Kebebasan Beragama/Berkeyakinan dan Toleransi 2010. Jakarta: The Wahid institute;

Wijaningsih, Dyah. "Perubahan Sosial dan Hukum (Dalam Ancangan dan Pemikiran)". J urnal Hukum, Vol 14 No. 1 Januari 2004 Fakultas Hukum Universitas Islam Sultan Agung Semarang;

Winata, Frans Hendra. "Agama Tidak Memerlukan Pengakuan Negara Secara Resmi dan Diatur Hukum". Jurnal Law Review, Vol VIII No. 1 J uli 2008. Jakarta: Fakultas Hukum Universitas Pelita Harapan. 